Published in final edited form as:

Curr Colorectal Cancer Rep. 2017 August ; 13(4): 341-351. doi:10.1007/s11888-017-0373-6.

\title{
Inflammation and Colorectal Cancer
}

\author{
Apple G. Long, MD, PhD ${ }^{1}$, Emma T. Lundsmith, $\mathbf{M D}^{2}$, and Kathryn E. Hamilton, $\mathrm{PhD}^{1}$ \\ ${ }^{1}$ Division of Gastroenterology, Department of Medicine, University of Pennsylvania Perelman \\ School of Medicine, Philadelphia, PA \\ 2Jefferson Medical College, Thomas Jefferson University, Philadelphia, PA
}

\begin{abstract}
Colorectal cancer (CRC) is the fourth most common cancer in both men and women in the United States, resulting in over 55,000 deaths annually. Environmental and genetic factors influence the development of CRC, and inflammation is a critical hallmark of cancer that may arise from a variety of factors.
\end{abstract}

Purpose of review-While patients with inflammatory bowel disease (IBD) have a higher risk of developing CRC, sporadic CRCs may engender or be potentiated by inflammation as well. In this review, we focus on recent advances in basic and translational research utilizing murine models to understand the contribution of inflammatory signaling pathways to CRC.

Recent findings-We discuss advances in the utility of three-dimensional enteroid/colonoid/ tumoroid cultures to understand immune-epithelial interactions in CRC, as well as the potential for utilizing patient-derived tumoroids for personalized therapies.

Summary-This review underscores the importance of understanding the complex molecular mechanisms underlying inflammation in sporadic CRC and highlights up-and-coming or new avenues for CRC biomarkers or therapies.

\section{Keywords}

inflammation; cytokines; sporadic colorectal cancer; inflammatory bowel disease; colitisassociated cancer; enteroids; colonoids; tumoroids; mouse models of colorectal cancer

\section{Introduction}

Colorectal cancer (CRC) is the fourth most common cancer in both men and women in the United States. Despite significant advancements in early diagnosis and treatment, it remains the third leading cause of cancer-related deaths in the United States and accounts for over 55,000 deaths annually [1]. Both environmental and genetic factors influence the

\footnotetext{
Corresponding author: Kathryn E. Hamilton, PhD, 421 Curie Blvd, $9^{\text {th }}$ Floor Biomedical Research Building, Philadelphia, PA 19104, Phone: 215-573-7314, Fax: 215-573-2024, haka@mail.med.upenn.edu.

Compliance with Ethics Guidelines

Human and Animal Rights and Informed Consent

This article does not contain any studies with human or animal subjects performed by any of the authors.

Conflict of Interest

Apple G. Long, Emma T. Lundsmith, and Kathryn E. Hamilton declare they have no conflict of interest.
} 
development of CRC, with $>70 \%$ of cases classified as sporadic. Patients with hereditary CRC syndromes such as familial adenomatous polyposis (FAP), Lynch syndrome, PeutzJegher's syndrome, Juvenile Polyposis syndrome, MUTYH associated polyposis (MAP) are at substantially increased risk for CRC, and, in some instances, cancers outside of the GI tract. Additionally, inflammatory bowel disease (IBD), in particular ulcerative colitis, represents a separate entity in which the risk of CRC is increased. The incidence of CRC in IBD patients (i.e., colitis-associated cancer or CAC) was reported to be up to $60 \%$ higher than the general population [2]. Sporadic CRCs may also demonstrate a prominent inflammatory response, known as tumor-induced inflammation. Both sporadic CRC and CAC share similar genetic alterations; however, there are heterochronic differences in key genes or pathways that distinguish the two types. For example, early mutations in the tumor suppressor gene Adenometous Polyposis Coli (APC) are a key feature in sporadic CRC (subtype annotated by chromosomal instability), whereas $A P C$ mutations occur late in the progression of CAC; however, the converse has been demonstrated for tumor suppressor gene TP53 [3,4].

While inflammation is understood to be an important driver of tumorigenesis in CAC, the role of inflammation in sporadic and hereditary CRC is nuanced. Mounting evidence suggests that treatment with anti-inflammatory medications may prevent or delay the development of CRC in hereditary and sporadic cases [5], underscoring a potentially ubiquitous role of inflammation in the development and progression of all types of CRC. Recently, the description of four consensus molecular subtypes (CMSs) provided a means for grouping CRCs with distinguishing features, with the goal of promoting more effective and personalized therapeutic strategies [6-8•]. Within these subtypes, investigators have evaluated immune and stromal gene expression data [9]. Based on these studies, CMS1 ("MSI immune", 14\%) and CMS4 ("mesenchymal", 23\%) CRCs exhibit enrichment in lymphoid and myeloid-specific genes, suggesting that these subtypes of sporadic CRCs are "inflammatory". Critically, patients subtyped as CMS1 exhibited worse survival after relapse and CMS4 patients exhibited poorest overall and relapse-free survival [7]. Taken together, these data underscore the importance of a comprehensive understanding of inflammation in the context of sporadic CRC.

Inflammation is a hallmark of cancer and may arise from a variety of factors, including infection, environmental carcinogens (tobacco, alcohol, radiation), cellular senescence, and obesity [10,11]. Yet, inflammation can play dual roles in the context of cancer. Targeting of specific cancer cells by cytotoxic T-lymphocytes (CTLs) or dampening of nonspecific inflammation by regulatory $\mathrm{T}$ cells (T-regs) may contribute to an anti-tumorigenic response. These protective responses are commonly associated with Th1 polarization and correlate with reduced CRC recurrence [12]. The inflammasome complex can also induce cellular apoptosis in the context of foreign antigens or DNA damage via various sensors and inflammatory cascades [13]. In contrast, nonspecific chronic inflammation, observed frequently with Th17-related cytokines, provides proliferative signals or induces additional mutations to promote carcinogenesis, and is associated with poor survival $[12,14]$.

The important cell types in cancer-associated inflammation include the innate immune system (neutrophils, macrophages, innate lymphoid cells, intraepithelial lymphocytes, 
myeloid-derived suppressor cells, natural killer cells), adaptive immune cells (B and T lymphocytes), intestinal epithelial cells (including Paneth cells), and other stromal cells (fibroblasts, endothelial cells/pericytes, mesenchymal cells, adipocytes, and neurons) [10]. Cross-talk among these cell types is predominantly through a network of cytokines, chemokines, and other growth factors. Specific signaling of these secreted factors is dependent on receptor availability among these cells and can induce either tumoricidal or growth-promoting activities. In the current review, we will summarize recent advances in our understanding of inflammation and colorectal cancer, with an emphasis on trends in basic and translational research from the past five years.

\section{Inflammatory signaling pathways in colorectal cancer: insights from murine models}

Current knowledge in understanding the inflammatory factors of CRC has been elucidated through analysis of two major mouse models (Table I). Treatment of mice with dextran sulfate sodium (DSS) has been used since the early 1990s to mimic chronic inflammation and tumor formation in the colon, reflective of CAC $[15,16]$. Multiple rounds of DSS in drinking water, followed by a latency period, induces sessile lesions and rates of dysplasia and adenocarcinoma similar to those seen in ulcerative colitis (UC) patients (i.e., 15-20\%), a subtype of IBD. Azoxymethane (AOM), a carcinogen is added to this model to improve efficiency of dysplasia and adenocarcinoma development.. AOM with DSS induces stabilization and nuclear translocation of $\beta$-Catenin by mutating exon 3 of the Ctnnb1 gene $[17,18]$, as well as by causing common molecular changes in CRC, such as upregulation of COX-2 and iNOS, and p53 loss [17].

A second mouse model of CRC utilizes mutations in the adenomatous polyposis coli ( $A p c)$ gene, and reflects many features of sporadic CRC. Mutations in $A P C$ were first described in patients with FAP, a hereditary form of CRC, which begins with florid adenoma development in the colon and $100 \%$ rate of progression to adenocarcinoma [19]. APC sequesters $\beta$-catenin in the cytoplasm, thus preventing the nuclear translocation of $\beta$-catenin and transcription of pro-proliferative genes in the Wnt signaling pathway, such as $C C N D 1$ and $M Y C$ [20]. Mutations in $A P C$ are also commonly found in sporadic colorectal cancer [21]. A mouse model derived from a chemical mutagenesis screen was found to have multiple intestinal neoplasia ( $\mathrm{min}$ ) and was later mapped to a truncating mutation in the $A p c$ gene [22,23]. Interestingly, these mice exhibited a small intestinal phenotype, whereas humans with $A P C$ mutation develop adenomas in the colon. Other truncations in $A p c$ are also utilized to model CRC, with varying tumor penetration and location of disease (Table 1). By utilizing targeted mutations of $A p c$ with specific promoters, such as $C d x 2$, investigators are able to better reflect human disease with a distal colonic distribution of lesions [24]. Most studies evaluating inflammatory mechanisms in CRC utilize one or both of the above-described models, which are summarized in Table 1.

\section{Interleukin-10 (IL-10)}

The role of IL-10 in CRC remains controversial, as elevated serum levels correlate with poorer survival in humans [25], while several mouse models have demonstrated protective 
roles of IL-10 in the context of both down regulating inflammation as well as promoting cytotoxic functions. Global IL-10-deficient mice developed severe colitis and adenocarcinoma of the colon by 6 months of age [26]. These pathological changes were marked by increased levels of $\mathrm{CD}^{+}$cells and macrophages in the lamina propria, along with associated elevated levels of TNFa, IL-6 and nitric oxide (NO) [26,27]. In CAC, IL-10 may be critical in limiting a pathogenic Th17 inflammatory response [28]. Consistent with murine studies, impaired IL-10 signaling is observed in IBD patients, and mutations in the IL-10 receptor have been described in Crohn's disease [29]. In a spontaneous CRC model with an $A p c^{\Delta 468}$ mutation, ablation of IL-10 in the T-cell-only population phenocopied the polyposis and inflammation of ubiquitous IL-10 loss, suggesting that T-cells are a main contributors to inflammation in the colon [30••]. In the small intestines, polyposis development was initially delayed, but mice that lacked IL-10 in the T-cell compartment eventually succumbed to more invasive carcinoma [31]. Th1 expansion was impaired, and defective IFN- $\gamma$ dependent cytotoxic functions contributed to the expansion of the polyposis, suggesting a crucial role of IL-10 in tumor surveillance. Through phase inversion nanoencapsulation delivery of IL-10 in $A p c^{\mathrm{min} /+}$ mice, suppression of pathogenic Tregs was achieved via suppression of IL-17. Treated mice exhibited decreased polyp burden and severity of disease pathology in the intestines [32••].

\section{Interferons (IFN)}

IFNs have been previously well described in providing host immunity, as they are produced by Th1 $\mathrm{CD}^{+}$, cytotoxic $\mathrm{CD}^{+}$, and natural killer (NK) cells in order to induce apoptosis in effector downstream cells [33]. Of note, IFN- $\gamma$ may also be produced by Th17 cells to induce pathogenic responses [34]. Nevertheless, loss of one copy of IFN- $\gamma$, a type II interferon in the background of $A p c^{\mathrm{min} /+}$ mice demonstrated faster progression to colonic adenocarcinoma, through elevated expression of $W n t 2$ and elevated levels of activated EGFR and ERK1/2 [35]. A mechanism by which CRC cells evade the tumoricidal effects of interferon signaling is through downregulation of type I interferon receptor chain IFNAR1, which limits the therapeutic response of anti-PD1 therapy, an immune checkpoint inhibitor [36]. InfraS526A mice, which are deficient in ubiquitination and proteasomal degradation of INFAR1, exhibited a significant reduction in tumor number and prolonged survival compared to wildtype controls in CAC. Pharmacological stabilization of INFAR1 through small molecules that inhibit p38a and protein kinase 2 (PKD2), two kinases that downregulate INFAR1, inhibited tumor growth in an implantable model of CRC. Considering the dose-limiting side effects of interferon therapy, the stabilization of interferon receptors in conjunction with immune checkpoint inhibitor therapies may be an avenue of further investigation in CRC treatment.

\section{IL-23/IL-17 axis}

Th17 cell polarization and production of its related cytokines, IL-17A, IL-17F, IL-21, IL-22, TNF- $a$, and IL-6 provide a pro-tumorigenic inflammatory response and are frequently associated with poor prognosis in CRC [12,37]. During homeostasis, Th17 cells exert host defenses against microbial substances and have been implicated in a variety of autoimmune diseases, such as IBD, psoriasis and rheumatoid arthritis [38]. In contrast, in CRC effector functions of Th17-related cytokines include the following: promoting pro-growth STAT3, 
$\mathrm{NF}-\kappa \mathrm{B}$, and $\beta$-catenin pathways; recruitment of myeloid derived tumor cells (MDSC) in order to promote a immunosuppressive environment; and induction of pro-angiogenic factors [37]. In both sporadic CRC and CAC mouse models, IL-23 induces Th17 cell activation, which accelerates and increases tumor load [14••]. Barrier defects during CRC progression increase penetration of microbial products to drive IL-23 production by tumorassociated myeloid cells. Interestingly, NADPH oxidase protein p47PHOX acts upstream of IL-23 but negatively regulates IL-12 (a regulator of Th1 differentiation) [39]. IL-17A may be a key effector of the Th17 response, as II17ra knockout mice in CAC showed similar results in reduced tumor burden. IL-17C, also produced by Th17 cells, can promote cancer cell survival through activation of BCL-2 and BCL- $\mathrm{X}_{\mathrm{L}}$ [40]. In an infectious mouse model of CAC, innate lymphoid cells (ILCs) can contribute to the Th17-related cytokine population and drive invasive tumor progression through STAT3 signaling [41]. Depletion of ILCs or their cytokine products, IL-22, IL-17, or IFN- $\gamma$, reduced the presence of tumors [41]. In contrast, in human cancers, IL-17 is predominantly produced by $\gamma \delta \mathrm{T}$ cells, which are activated by IL-23 from tumor infiltrating dendritic cells and elicit MDSC-mediated immunosuppression to promote tumorigenesis [42].

\section{Interleukin-6 (IL-6)/Signal transducer and activator of transcription 3(STAT3) signaling pathway}

IL-6 is frequently found in the tumor milieu of both mouse and human CRCs, and is associated with poorer survival and relapse [43,44]. IL-6 induced Th17 cell differentiation and regulated downstream STAT3 signaling in order to induce survival and proliferation of cancer cells $[45,46]$. STAT3, a transcription factor that is induced by gp130 dimerization (upon binding of IL-6 or IL-11), promoted tumor growth and induced anti-tumoral immunity specifically through the epithelial compartment $[47,48]$. Recently, IL-11, a member of the IL-6 family, has been shown to be an effective promoter of tumorigenesis in mouse CAC and associated with STAT3 activation in human samples [49]. Mutein, a potent IL-11 antagonist, reduced tumor number and size by limiting STAT3 activation and its downstream effects [49]. Inhibiting STAT3 signaling with NT157, an inhibitor of insulin-like growth factor-1 (IGFR-1R), also reduced tumor burden in sporadic models of mouse CRC [50]. IL-22, which has previously been ascribed to protect epithelial cells from bacterial infection or inflammatory damage, induced epithelial STAT3 activation, in order to drive cancer stemness, via upregulation the methyltransferase DOT1L [51•]. Altogether, convergence of multiple pathways on STAT3 signaling support the notion of STAT3 as a critical node in CRC progression and immune evasion and a potent avenue for therapeutic targeting, as targeting of single cytokines or even groups of cytokines may not fully inhibit STAT3 activation effectively [52].

\section{NF- $x B$ signaling}

NF- $\kappa B$ signaling is an integral promoter of inflammation in both homeostasis and cancer, with multiple downstream targets such as IL-6, IL-8, and COX-2, among others [53]. In the context of the gut, loss of NF- $\mathrm{\kappa B}$ signaling in the epithelial compartment demonstrated increased susceptibility to inflammation but protection from tumorigenesis, through increased apoptosis, via upregulation of the Bcl- $\mathrm{X}_{\mathrm{L}}$ pathway [18,54]. Correspondingly, constitutively active IKK $\beta$ (a kinase in the NF- $\kappa$ B signaling pathway) in the epithelial 
compartment led to prolonged activation of NF- $\mathrm{KB}$ and accelerated development of colorectal tumors with increased DNA damage, associated with iNOS up-regulation [55]. Loss of IKK $\beta$ in the myeloid compartment reduced pro-inflammatory mediators and slowed tumor growth [18]. NF- $\mathrm{\kappa B}$ signaling in intestinal mesenchymal cells has recently been shown to promote tumorigenesis, but only in the setting of CAC and not spontaneous CRC, suggesting that NF- $\mathrm{KB}$ may be critical in perpetuating inflammation [56]. Interestingly, mutant $\mathrm{p} 53$ (in cancer cells) can prolong NF- $\kappa \mathrm{B}$ activity by co-opting activators to NF- $\kappa \mathrm{B}$ response elements and drive CAC by increasing levels of IL-8 and Il-6 [57]. Considering that p53 mutation is an early event during CAC, earlier genetic screening of IBD patients for mutations in $\mathrm{p} 53$ warrants further investigation.

\section{PGE2 pathway}

The role of NSAIDs in reducing the relative risk of colorectal adenoma underscores the contribution of the cyclooxygenase pathway in the pathogenesis of disease [5]. The cyclooxygenases COX1 and COX2 are enzymes that convert arachidonic acid to prostaglandin G2 and then to prostaglandin H2. Disruption of the gene encoding COX2, Ptgs2, in sporadic mouse models of CRC demonstrated reduction in tumorigenesis [58,59]. These data are supported by similar phenotypes in $\operatorname{Ptgs} 1$ knockout mice and in complementary experiments of prostaglandin treatment in mice [59]. Many of these earlier studies proposed that COX-2's role in generating PGE2 is important for angiogenesis, cell survival and activation of WNT pathways [60]. More recently, PGE2 was shown to be involved in immune evasion by modulating bone marrow derived mononuclear cells [61]. In an implantable model of colorectal cancer cell lines, COX-2 inhibition along with PD-1 inhibition had additive effects in inducing tumor regression. Therapeutically, there may be additional benefits of combining PD-1 blockade along with COX-2 inhibition. To date, there have been two phase 2 trials examining the effects of PD-1 inhibition on microsatellite instability positive metastatic colorectal cancer [62] an area that is receiving much attention.

\section{Epithelial cells in colorectal cancer inflammation}

\section{Inflammatory mediators in tumor-initiating cells}

Tumor-initiating cells (TICs) are a sub-population of the bulk tumor that harbors "stem-like" characteristics and are thought to confer resistance to therapies. In CRC, TIC's may be identified by a combination of surface expression markers including CD24, CD44, CD133, and ALDH1, among others [63-65]. Mounting evidence suggests functional roles for inflammation in driving TIC phenotypes in CRC, likely via convergence with canonical stem cell pathways (i.e. Wnt signaling). Several studies have demonstrated that CRC TICs express high levels of phosphorylated STAT3 and are sensitive to STAT3 inhibition [66,67]. A recent study by Kryczek et al. revealed that IL-22 produced by CD4+ T-cells led to induction of STAT3, which conferred CRC cell "stemness" [51•]. This is consistent with data in normal intestine demonstrating that IL-22 enhances organoid growth in a STAT3dependent manner [68]. Similarly, high levels of NF- $\kappa B$ have been described in cells with a TIC phenotype [68], and studies suggest that NF- $\kappa$ B enhances Wnt activation and tumorinitiating capacity $[70,71]$. 


\section{Paneth cells are hubs for epithelial inflammation}

Paneth cells are specialized, secretory cells located at the intestinal crypt base, where they secrete antimicrobial products and stem cell nice factors [72]. Paneth cell dysfunction has been demonstrated to promote inflammation or susceptibility to inflammation, contributing to the notion of Paneth cells as a hub of epithelial cell inflammation and homeostasis $[72,73]$. While Paneth cells are abundant in the small intestine, they are sparsely found in the normal colon and restricted to the proximal region. The presence of Paneth cells outside of the small intestine is commonly referred to as Paneth cell metaplasia, and can be found in patients with IBD and colorectal cancer [74-77]. Recent studies have correlated Paneth cellcontaining adenomas with increased risk of colorectal neoplasia [78], whereas other studies found no association between Paneth cells and synchronous advanced adenoma or colorectal carcinoma [79]. In mice, overexpression of the R-spondin gene Rspo3, which potentiates Wnt signaling in the gut, promotes expansion of $L g r 5$ stem cells and Paneth cells, with Paneth cells located throughout adenomas and at the invasive front of adenocarcinomas [80•]. Feng et al. described ectopic Paneth-like cells in colonic epithelium of mice with biallelic inactivation of $A p c$, yet, the specific contribution of these cells to the pathogenesis of colorectal cancer remains unknown [74]. Recently, intestinal epithelial-specific deletion of protein kinase $\mathrm{C}(\mathrm{PKC}) \lambda / \imath$ demonstrated decreased Paneth cell numbers, spontaneous intestinal inflammation, and enhanced tumorigenesis associated with increased inflammation [81•]. The intimate association of Paneth cells, inflammation, and the Wnt pathway suggest that Paneth cells contribute to inflammation preceding or during sporadic colorectal cancer. It remains unclear whether Paneth cells themselves can function as TICs or drivers of colorectal cancer.

\section{Three-dimensional primary cultures to evaluate the role of inflammation in colon carcinogenesis}

Studies in cell lines and mouse models are critical to advancing our understanding of the pathways driving inflammation-associated carcinogenesis, yet translating new findings to patient care remains a consistent challenge. Recently, enteroids/colonoids (threedimensional (3D) cultures derived from normal, stem cell-containing intestine/colon) and tumoroids (3D cultures derived directly from tumors) have gained traction as tools for mechanistic studies as well as to fill an important, pre-clinical gap between basic science discovery and clinical utility $[82,83]$. The development of a readily reproducible 3D culture system for normal intestinal and colon stem cells was first described in 2009 [84], and this technique has since evolved as a new tool in the study of colorectal cancer $[82,83,85,86]$. Evaluation of morphological and phenotypic parameters of colonoids/tumoroids provides a more physiological environment than 2D cell culture and, importantly for the evaluation inflammation-associated colorectal cancer, a means to evaluate specific mechanisms ex vivo as well as inflammatory niche factors on cell survival and proliferation.

In recent years, there has been an increase in studies utilizing 3D cultures to dissect specific mechanisms of inflammation and colorectal cancer. Recent studies demonstrated that sequential, CRISPR/Cas9-mediated mutations in APC, TP53, SMAD4, K-RAS, and $P I K 3 C A$ in human colonoids can recapitulate growth in the absence of exogenous growth 
factors in vitro, as well as the ability to grow in transplantation models [87]. It would be interesting to recapitulate these experiments using inflammatory or para-inflammatory gene mutations to study the step-wise mutational progression in inflammation-associated or colitis-associated CRC. Indeed, numerous studies have described mechanisms of crosstalk between Wnt signaling, proliferation, and inflammatory pathways (STAT3, NFkB) in the gut [47,70,88-80]. Additional studies have utilized enteroids to understand epithelial cellspecific mechanisms in knockout mice exhibiting increased or decreased susceptibility to AOM/DSS treatment. For example, enteroids from selenoprotein P (SEPP1) knockout mice, which exhibit decreased susceptibility to AOM/DSS tumorigenesis, displayed increased proliferation, increased reactive oxygen species (ROS) production and DNA damage, and decreased survival following $\mathrm{H}_{2} \mathrm{O}_{2}$ treatment, suggesting a distinct role for epithelial SEPP1 in colon tumorigenesis [90]. This is consistent with the notion that proliferation, downstream of inflammation, may set the stage for enhanced DNA damage and mutations [92].

In addition to evaluating epithelial cell-autonomous effects in enteroids, stromal cells can be co-cultured with epithelial enteroids/colonoids in order to dissect mechanisms of specific cell-cell interactions. Stromal populations co-cultured with intestine/colon organoids include intraepithelial lymphocytes (IELs, a heterogenous T-cell population), macrophages, intestinal myofibroblasts, and neurons [93•-96]. A recent co-culture study using normal intestinal enteroids together with IELs demonstrated an increase in IEL numbers with cytokine (IL-2/-7/-15) stimulation, thus combining co-culture approaches with evaluation of exogenous inflammatory niche factors [93•]. Future strategies may include utilizing enteroid/colonoid co-cultures to pair isolated stromal/immune cells from CRC patients (or mouse models) with healthy colonoids (and vice versa) in order to understand the relative and specific contributions of each cell type (Figure 1). In addition, co-culturing with other pro-tumorigenic stromal cells (granulocytes, endothelial cells, pericytes) or perhaps multiple stromal cell types together will allow for in vitro recapitulation of the inflammatory microenvironment with tumoroids that may facilitate discovery more quickly than complex genetic mouse models.

\section{Conclusions}

Understanding the role of specific inflammatory mediators in CRC is essential for improving screening, diagnosis, and therapeutic strategies for patients. While the essential inflammatory pathways (STAT3, NF- $\mathrm{BB}$, and associated cytokines) are themselves understood to be drivers of inflammation and tumorigenesis, the relative contribution, crosstalk, and cell-type specific effects are only recently being comprehensively defined. In addition, alterations in the gut microbiome contribute to the pathogenesis of colorectal cancer in the context of inflammation. The generation and characterization of geneticallyengineered mouse models is critical to advancing our understanding of the complex roles of inflammatory signaling cascades in CRC, and the advent of CRISPR/Cas9 approaches for mouse genome editing will likely accelerate the ability to test cell type-specific effects of multiple pathways within the same animal. In addition, 3D enteroid/colonoid/tumoroid cultures may be utilized as tools for understanding mechanisms of crosstalk between epithelial and inflammatory/stromal cells, and patient-derived cultures will allow for characterization and therapeutic evaluation for personalized care. With the incorporation of 
existing and new technologies, including mouse models and 3D cultures, we will continue to develop our understanding of the intimate relationship between inflammation and CRC in order to improve therapies for CRC.

\section{References}

Papers of particular interest, published recently, have been highlighted as:

- Of importance

•• Of outstanding importance

1. Howlader, N., Noone, AM., Krapcho, M., et al. Natl. Cancer Institute. Bethesda, MD: 2016. SEER Cancer Statistics Review, 1975-2013. [Internet]. Available from: http://seer.cancer.gov/csr/ 1975_2013/

2. Dulai PS, Sandborn WJ, Gupta S. Colorectal Cancer and Dysplasia in Inflammatory Bowel Disease: A Review of Disease Epidemiology, Pathophysiology, and Management. Cancer Prev. Res. 2016; 9:887-94. [Internet]. Available from: http://cancerpreventionresearch.aacrjournals.org/content/early/ 2016/11/07/1940-6207.CAPR-16-0124.abstract.

3. Fearon EF, Vogelstein B. A Genetic Model for Colorectal Tumorigenesis. Cell. 1990; 61:759-67. [PubMed: 2188735]

4. Kern SE, Redston M, Seymour aB, Caldas C, Powell SM, Kornacki S, et al. Molecular genetic profiles of colitis-associated neoplasms. Gastroenterology. 1994; 107:420-8. [PubMed: 8039618]

5. Friis S, Riis AH, Erichsen R, Baron JA, Sorensen HT. Low-dose aspirin or nonsteroidal antiinflammatory drug use and colorectal cancer risk: A population-based, case-control study. Ann. Intern. Med. 2015; 163:347-55. [PubMed: 26302241]

6. Graham DM, Coyle VM, Kennedy RD, Wilson RH. Molecular Subtypes and Personalized Therapy in Metastatic Colorectal Cancer. Curr. Colorectal Cancer Rep. 2016:141-50. [PubMed: 27340376]

7••. Guinney J, Dienstmann R, Wang X, de Reyniès A, Schlicker A, Soneson C, et al. The consensus molecular subtypes of colorectal cancer. Nat. Med. 2015; 21:1350-6. Describes novel classification system for CRC via coalescence of six independent CRC classification systems into four consensus molecular subtypes (CMS). [PubMed: 26457759]

8•. Müller MF, Ibrahim AEK, Arends MJ. Molecular pathological classification of colorectal cancer. Virchows Arch. 2016:125-34. Evaluates molecular changes in genetic instability in CRC and describes majority of hypermutated microsatellite instability (MSI) cancers falling into consensus molecular subtype 1 (CMS1, MSI-immune).

9. Becht E, De Reyniies A, Giraldo NA, Pilati C, Buttard B, Lacroix L, et al. Immune and stromal classification of colorectal cancer is associated with molecular subtypes and relevant for precision immunotherapy. Clin. Cancer Res. 2016; 22:4057-66. [PubMed: 26994146]

10. Terzic J, Karin E, Karin M. Inflammation and Colon Cancer. Gastroenterology. 2010:2101-14. [PubMed: 20420949]

11. Calle EE. Obesity and cancer. Br. Med. J. 2007; 335:1107-8. [PubMed: 17986715]

12. Galon J, Costes A, Sanchez-Cabo F, Kirilovsky A, Mlecnik B, Lagorce-Pagès C, et al. Type, density, and location of immune cells within human colorectal tumors predict clinical outcome. Science. 2006; 313:1960-4. [PubMed: 17008531]

13. Lasry A, Zinger A, Ben-neriah Y. Review Inflammatory networks underlying colorectal cancer. Nature Immunology. 2016:17.

14••. Grivennikov SI, Wang K, Mucida D, Stewart CA, Schnabl B, Jauch D, et al. Adenoma-linked barrier defects and microbial products drive IL-23/IL-17-mediated tumour growth. Nature. 2012; 491:254-8. Demonstrates role of IL-23 in eliciting Th17 pro-tumoriencic responses. [PubMed: 23034650]

15. Okayasu, Isao, Hatakeyama, Shigeru, Yamada, Masahiro, Ohkusa, Toshifumi, Inagaki, Yoshio, Nakaya, R. A Novel Method in the Induction of Reliable Experimental Acute and Chronic Ulcerative Colitis in Mice. Gastroenterology. 1990; 98:694-702. [PubMed: 1688816] 
16. Cooper, Harry S., Murthy, SNS., Shah, Rupal, Sedergran, DJ. Clinicopathologic Study of Dextran Sulfate Sodium Experimental Murine Colitis. Lab. Investig. 1993; 69:238-49. [PubMed: 8350599]

17. Tanaka T, Kohno H, Suzuki R, Yamada Y, Sugie S, Mori H. A novel inflammation-related mouse colon carcinogenesis model induced by azoxymethane and dextran sodium sulfate. Cancer Science. 2003; 94:965-73. [PubMed: 14611673]

18. Greten FR, Eckmann L, Greten TF, Park JM, Li Z, Egan LJ, et al. IKK-beta Links Inflammation and Tumorigenesis in a Mouse Model of Colitis-Associated Cancer. Cell. 2004; 118:285-96. [PubMed: 15294155]

19. Groden J, Thliveris A, Samowitz W, Carlson M, Gelbert L, Albertsen H, et al. Identification and characterization of the familial adenomatous polyposis coli gene. Cell. 1991:589-600. [PubMed: 1651174]

20. Polakis P. Wnt signaling in cancer. Cold Spring Harb. Perspect. Biol. 2012; 4(5)

21. The Cancer Genome Atlas Network, Comprehesive molecular characterization of human colon and rectal cancer. Nature. 2012; 487:330-337. [PubMed: 22810696]

22. Rapaich A, Pitot HC, Dove WF, Moser AMYR, Pitot HC, Dove WF. A Dominant Mutation That Predisposes to Multiple Intestinal Neoplasia in the Mouse Published by: American Association for the Advancement of Science Stable. A Dominant Mutation That Predisposes to Multiple Intesti. 1990; 247:322-4. URL : http://www.jstor.org/stable/2873632.

23. Su L, Kinzler KW, Vogelstein B, Preisinger AC, Moser R, Luongo C, et al. Multiple Intestinal Neoplasia Caused by a Mutation in the Murine Homolog of the APC Gene Published by: American Association for the Advancement of Science Stable. Multiple Intestinal Neoplasia Caused by a Mutation. 1992; 256:668-70. URL : http://www.jstor.org/stable/2876870.

24. Hinoi T, Akyol A, Theisen BK, Ferguson DO, Greenson JK, Williams BO, et al. Mouse Model of Colonic Adenoma-Carcinoma Progression Based on Somatic Apc Inactivation. Cancer Research. 2007:9721-30. [PubMed: 17942902]

25. Stanilov NS, Miteva L, Cirovski G, Stanilova SA. Increased transforming growth factor $\beta$ and interleukin 10 transcripts in peripheral blood mononuclear cells of colorectal cancer patients. Contemp. Oncol. 2016; 20:458-62.

26. Berg DJ, Davidson N, Kühn R, Müller W, Menon S, Holland G, et al. Enterocolitis and Colon Cancer in Interleukin-10 - deficient Mice Are Associated with Aberrant Cytokine Production and CD4 8 TH1-like Responses. J Clin Invest. 1996; 98(4):1010-20. [PubMed: 8770874]

27. Davidson NJ, Leach MW, Fort MM, Thompson-snipes L, Kiihnfl R, Mi W, et al. T Helper Cell 1type C D 4 + T Cells, but Not B Cells, Mediate Colitis in Interleukin 10-deficient Mice. J Exp Med. 1996:184.

28. Chaudhry A, Samstein RM, Treuting P, Liang Y, Pils MC, Heinrich J, et al. Interleukin-10 Signaling in Regulatory T Cells Is Required for Suppression of Th17 Cell-Mediated Inflammation. Immunity. 2011; 34(4):566-78. [PubMed: 21511185]

29. Glocker E-O, Kotlarz D, Boztug K, Gertz EM, Schäffer AA, Noyan F, et al. Inflammatory bowel disease and mutations affecting the interleukin-10 receptor. N. Engl. J. Med. 2009; 361:2033-45. [PubMed: 19890111]

30••. Dennis KL, Wang Y, Blatner NR, Wang S, Saadalla A, Trudeau E, et al. Adenomatous Polyps Are Driven by Microbe-Instigated Focal In fl ammation and Are Controlled by IL-10 Producing T Cells. Cancer Res. 2013; 73(19):5905-13. Described influence of microbiota on eliciting IL-10 response and requirement of IL-10 to donwregulate tumorigenesis. [PubMed: 23955389]

31. Dennis KL, Saadalla A, Blatner NR, Wang S, Venkateswaran V, Gounari F, et al. T-cell Expression of IL10 Is Essential for Tumor Immune Surveillance in the Small Intestine. Cancer Immunol Res. 2015; 3:806-15. [PubMed: 25855122]

32•. Chung AY, Li Q, Blair SJ, De Jesus M, Dennis KL, Levea C, et al. Oral interleukin-10 alleviates polyposis via neutralization of pathogenic T-regulatory cells. Cancer Res. 2014; 74:5377-85. Showed that oral IL-10 administration can downregulate pathogenic Th17 response in order to reduce tumor size and incidence. [PubMed: 25228656]

33. Parker BS, Rautela J, Hertzog PJ. Review. Antitumour actions of interferons: Implications for cancer therapy. Nature Rev. Cancer. 2016; 16:131-44. [PubMed: 26911188] 
34. McGovern D, Powrie F. The IL23 axis plays a key role in the pathogenesis of IBD. Gut. 2007; 56:1333-6. [PubMed: 17872562]

35. Wang L, Wang Y, Song Z, Chu J, Qu X, Al WET. Deficiency of Interferon-Gamma or Its Receptor Promotes Colorectal Cancer Development. 2015; 35:273-80.

36••. Katlinski KV, Gui J, Katlinskaya YV, Koumenis C, Rui H, Fuchs SY. Inactivation of Interferon Receptor Promotes the Establishment of Immune Privileged Tumor Article Inactivation of Interferon Receptor Promotes the Establishment of Immune Privileged Tumor Microenvironment. Cancer Cell. 2017:194-207. Demonstrates that tumor cells can downregulate type I interferon receptors to reduce effectiveness of PD-1 blockade. Stabilization of INFRa decreases tumor size and incidence. [PubMed: 28196594]

37. Simone, V De, Pallone, F., Monteleone, G., Simone, V De, Pallone, F., Monteleone, G., et al. Role of T H 17 cytokines in the control of colorectal cancer. Oncoimmunology. 2013; 2(12):e26617. [PubMed: 24498548]

38. Tesmer LA, Lundy SK, Sarkar S, Fox DA. Review. Th17 cells in human disease. Immunol. Rev. 2008:87-113.

39. Richter C, Herrero San Juan M, Weigmann B, Bergis D, Dauber K, Muders MH, et al. Defective IL-23/IL-17 Axis Protects p47phox-/- Mice from Colon Cancer. Front. Immunol. 2017; 8:1-10. [PubMed: 28149297]

40. Song X, Gao H, Lin Y, Yao Y, Zhu S, Wang J, et al. Alterations in the Microbiota Drive Interleukin-17C Production from Intestinal Epithelial Cells to Promote Tumorigenesis. Immunity. 2013; 40:140-52.

41. Kirchberger S, Royston DJ, Boulard O, Thornton E, Franchini F, Szabady RL, et al. Innate lymphoid cells sustain colon cancer through production of interleukin-22 in a mouse model. J. Exp. Med. 2013; 210:917-31. [PubMed: 23589566]

42. Wu P, Wu D, Ni C, Ye J, Chen W, Hu G, et al. ydT17 cells promote the accumulation and expansion of myeloid-derived suppressor cells in human colorectal cancer. Immunity. 2014; 40:785-800. [PubMed: 24816404]

43. Heikkila K, Ebrahim S, Lawlor DA. Systematic review of the association between circulating interleukin-6 (IL-6) and cancer. Eur J Cancer. 2008; 44:937-45. [PubMed: 18387296]

44. Olsen J, Kirkeby LT, Olsen J, Eiholm S, Jess PER, Gögenur I, et al. High Interleukin-6 mRNA Expression Is a Predictor of Relapse in Colon Cancer. Anticancer Res. 2015; 2240:2235-40.

45. Zhou L, Ivanov II, Spolski R, Min R, Shenderov K, Egawa T, et al. IL-6 programs TH-17 cell differentiation by promoting sequential engagement of the IL-21 and IL-23 pathways. Nature Immunology. 2007; 8:967-74. [PubMed: 17581537]

46. Grivennikov S, Karin E, Terzic J, Mucida D, Yu G, Vallabhapurapu S, et al. IL-6 and Stat3 Are Required for Survival of Intestinal Epithelial Cells and Development of Colitis-Associated Cancer. Cancer Cell. 2009:103-13.

47. Bollrath J, Phesse TJ, Burstin VA Von, Putoczki T, Bennecke M, Bateman T, et al. Article gp130Mediated Stat3 Activation in Enterocytes Regulates Cell Survival and Cell-Cycle Progression during Colitis-Associated Tumorigenesis. Cancer Cell. 2009:91-102.

48. Yu H, Pardoll D, Jove R. Review. STATs in cancer inflammation and immunity : a leading role for STAT3. Nat Rev Cancer. 2009:798-809. [PubMed: 19851315]

49. Putoczki TL, Thiem S, Loving A, Busuttil RA, Wilson NJ, Ziegler PK, et al. Interleukin-11 Is the Dominant IL-6 Family Cytokine during Gastrointestinal Tumorigenesis and Can Be Targeted Therapeutically. Cancer Cell. 2013; 24:257-71. [PubMed: 23948300]

50. Sanchez-Lopez E, Flashner-Abramson E, Shalapour S, Zhong Z, Taniguchi K, Levitzki a, et al. Targeting colorectal cancer via its microenvironment by inhibiting IGF-1 receptor-insulin receptor substrate and STAT3 signaling. Oncogene. 2015; 35:1-11. [PubMed: 25893285]

51•. Kryczek I, Lin Y, Nagarsheth N, Peng D, Zhao L, Zhao E, et al. Stemness via STAT3 Transcription Factor Activation and Induction of the Methyltransferase DOT1L. Immunity. 2013; 40:772-84. Demonstrates a role for STAT3 signaling, in order to upregulate stemness genes through DOTL1, a methyltransferase.

Curr Colorectal Cancer Rep. Author manuscript; available in PMC 2018 August 01. 
52. Simone, V De, Franzè, E., Ronchetti, G., Colantoni, A., Fantini, MC., Fusco, D Di, et al. Th17type cytokines, IL-6 and TNF- a synergistically activate STAT3 and NF-kB to promote colorectal cancer cell growth. Oncogene. 2015:3493-503. [PubMed: 25174402]

53. Ben-Neriah Y, Karin M. Review. Inflammation meets cancer, with NF- $\kappa \mathrm{B}$ as the matchmaker. Nat. Immunol. 2011; 12:715-23. [PubMed: 21772280]

54. Nenci A, Becker C, Wullaert A, Gareus R, Loo G Van, Danese S, et al. Epithelial NEMO links innate immunity to chronic intestinal inflammation. Nature. 2007; 446:557-61. [PubMed: 17361131]

55. Shaked H, Hofseth LJ, Chumanevich A, Chumanevich AA, Wang J, Wang Y. Chronic epithelial NF- $\kappa$ B activation accelerates APC loss and intestinal tumor initiation through iNOS upregulation. Proc Natl Acad Sci. 2012; 109:14007-12. [PubMed: 22893683]

56. Koliaraki V, Pasparakis M, Kollias G. IKK $\beta$ in intestinal mesenchymal cells promotes initiation of colitis-associated cancer. J. Exp. Med. 2015; 212:2235-51. [PubMed: 26621453]

57 . Cooks T, Pateras IS, Tarcic O, Solomon H, Schetter AJ, Wilder S, et al. Mutant p53 Prolongs NF$\kappa \mathrm{B}$ Activation and Promotes Chronic Inflammation and Inflammation-Associated Colorectal Cancer. Cancer Cell. 2013; 23:634-46. Demonstrates that in mutant p53 had oncogenic functions in chronic colitis via NF- $\mathrm{kB}$ signaling, in order to promote invasive carcinoma. [PubMed: 23680148]

58. Oshima M, Dinchuk JE, Kargman SL, Oshima H, Hancock B, Kwong E, et al. Suppression of Intestinal Polyposis in Apc-delta 716 Knockout Mice by Inhibition of Cyclooxygenase 2 (COX-2). Cell. 1996; 87:803-9. [PubMed: 8945508]

59. Chulada PC, Thompson MB, Mahler JF, Doyle CM, Gaul BW, Lee C, et al. Genetic disruption of Ptgs-1, as well as of Ptgs-2, reduces intestinal tumorigenesis in Min mice. Cancer Res. 2000; 60:4705-8. [PubMed: 10987272]

60. Oshima H, Hioki K, Popivanova BK, Van Rooijen N, Ishikawa TO, Oshima M. Prostaglandin E 2 signaling and bacterial infection recruit tumor-promoting macrophages to mouse gastric tumors. Gastroenterology. 2011; 140:596-607. [PubMed: 21070778]

61. Zelenay S, Van Der Veen AG, Bottcher JP, Snelgrove KJ, Rogers N, Acton SE, et al. Cyclooxygenase-Dependent Tumor Growth through Evasion of Immunity. Cell. 2015; 162:125770. [PubMed: 26343581]

62. Le DT, Uram JN, Wang H, Bartlett BR, Kemberling H, Eyring AD, et al. PD-1 Blockade in Tumors with Mismatch-Repair Deficiency. N. Engl. J. Med. 2015; 372:2509-20. [PubMed: 26028255]

63. Garza-Treviño EN, Said-Fernández SL, Martínez-Rodríguez HG. Understanding the colon cancer stem cells and perspectives on treatment. Cancer Cell Int. 2015; 15:2. [PubMed: 25685060]

64. Diehn M, Cho RW, Lobo NA, Kalisky T, Jo M, Kulp AN, et al. Association of reactive oxygen species levels and radioresistance in cancer stem cells. 2009; 458:780-3.

65. O'Brien CA, Kreso A, Ryan P, Hermans KG, Gibson L, Wang Y, et al. ID1 and ID3 Regulate the Self-Renewal Capacity of Human Colon Cancer-Initiating Cells through p21. Cancer Cell. 2012; 21:777-92. [PubMed: 22698403]

66. Lin L, Liu A, Peng Z, Lin HJ, Li PK, Li C, et al. STAT3 is necessary for proliferation and survival in colon cancer-initiating cells. Cancer Res. 2011; 71:7226-37. [PubMed: 21900397]

67. Spitzner M, Roesler B, Bielfeld C, Emons G, Gaedcke J, Wolff HA, et al. STAT3 inhibition sensitizes colorectal cancer to chemoradiotherapy in vitro and in vivo. Int. J. Cancer. 2014; 134:997-1007. [PubMed: 23934972]

68. Lindemans CA, Calafiore M, Mertelsmann AM, O’Connor MH, Dudakov JA, Jenq RR, et al. Interleukin-22 promotes intestinal-stem-cell-mediated epithelial regeneration. Nature. 2015; 528:560-4. [PubMed: 26649819]

69. Rowehl RA, Burke S, Bialkowska AB, Pettet DW, Rowehl L, Li E, et al. Establishment of highly tumorigenic human colorectal cancer cell line (CR4) with properties of putative cancer stem cells. PLoS One. 2014:9.

70. Schwitalla S, Fingerle AA, Cammareri P, Nebelsiek T, Göktuna SI, Ziegler PK, et al. Intestinal tumorigenesis initiated by dedifferentiation and acquisition of stem-cell-like properties. Cell. 2013; 152:25-38. [PubMed: 23273993] 
71. Myant KB, Cammareri P, McGhee EJ, Ridgway RA, Huels DJ, Cordero JB, et al. ROS production and NF-kappaB activation triggered by RAC1 facilitate WNT-driven intestinal stem cell proliferation and colorectal cancer initiation. Cell Stem Cell. 2013; 12:761-73. [PubMed: 23665120]

72. Clevers HC, Bevins CL. Paneth cells: maestros of the small intestinal crypts. Annu. Rev. Physiol. 2013; 75:289-311. [PubMed: 23398152]

73. Adolph TE, Tomczak MF, Niederreiter L, Ko H-J, Bock J, Martinez-naves E, et al. Paneth cells as a site of origin for intestinal inflammation. Nature. 2013; 503:272-6. [PubMed: 24089213]

74•. Feng Y, Sentani K, Wiese A, Sands E, Green M, Bommer GT, et al. Sox9 induction, ectopic paneth cells, and mitotic spindle axis defects in mouse colon adenomatous epithelium arising from conditional biallelic Apc inactivation. Am. J. Pathol. 2013; 183:493-503. Describes ectopic Paneth cell expression driven by Apc inactivation in Cdx2-CreER(T2) model of colon tumorigenesis. [PubMed: 23769888]

75. Joo M, Shahsafaei A, Odze RD. Paneth cell differentiation in colonic epithelial neoplasms: evidence for the role of the Apc/beta-catenin/Tcf pathway. Hum. Pathol. 2009; 40:872-80. [PubMed: 19269007]

76. Wada R. Proposal of a New Hypothesis on the Development of Colorectal Epithelial Neoplasia: Nonspecific Inflammation-Colorectal Paneth Cell Metaplasia-Colorectal Epithelial Neoplasia. Digestion. 2009; 79:9-12. [PubMed: 19153484]

77. Wang D, Peregrina K, Dhima E, Lin EY, Mariadason JM, Augenlicht LH. Paneth cell marker expression in intestinal villi and colon crypts characterizes dietary induced risk for mouse sporadic intestinal cancer. Proc. Natl. Acad. Sci. 2011; 108:10272-7. [PubMed: 21652773]

78. Pai RK, Rybicki LA, Goldblum JR, Shen B, Xiao S-Y, Liu X. Paneth Cells in Colonic Adenomas Association with Male Sex and Adenoma Burden. Am J Surg Pathol. 2013; 37:98-103. [PubMed: 23232853]

79. Mahon M, Xu J, Yi X, Liu X, Gao N, Zhang L. Paneth Cell in Adenomas of the Distal Colorectum Is Inversely Associated with Synchronous Advanced Adenoma and Carcinoma. Sci Rep. 2016:17. [PubMed: 28442746]

80•. Hilkens J, Timmer NC, Boer M, Ikink GJ, Schewe M, Sacchetti A, et al. RSPO3 expands intestinal stem cell and niche compartments and drives tumorigenesis. Gut. 2016 gutjnl-2016-311606. Describes overexpression of R-spondin 3 (RSPO3) in a subset of CRCs and uses a mouse model of conditional Rspo3 expression driven by Lgr5-GFP-CreER(T2) to demonstrate up-regulation of intestinal stem and Paneth cells as well as adenocarcinoma.

81•. Nakanishi Y, Reina-Campos M, Nakanishi N, Llado V, Elmen L, Peterson S, et al. Control of Paneth Cell Fate, Intestinal Inflammation, and Tumorigenesis by PKC $\lambda /$ I. Cell Rep. 2016; 16:3297-310. Highlights the role of protein kinase C (PKC) $\lambda / \imath$ in Paneth cell homeostasis, intestinal inflammation, and cancer. [PubMed: 27653691]

82. Fujii M, Shimokawa M, Date S, Takano A, Matano M, Nanki K, et al. A Colorectal Tumor Organoid Library Demonstrates Progressive Loss of Niche Factor Requirements during Tumorigenesis. Cell Stem Cell. 2016; 18:827-38. [PubMed: 27212702]

83. Young M, Reed KR. Organoids as a Model for Colorectal Cancer. Curr. Colorectal Cancer Rep. 2016:281-7. [PubMed: 27656116]

84. Sato T, Vries RG, Snippert HJ, van de Wetering M, Barker N, Stange DE, et al. Single Lgr5 stem cells build crypt-villus structures in vitro without a mesenchymal niche. Nature. 2009; 459:262-5. [PubMed: 19329995]

85. Van De Wetering M, Francies HE, Francis JM, Bounova G, Iorio F, Pronk A, et al. Prospective derivation of a living organoid biobank of colorectal cancer patients. Cell. 2015; 161:933-45. [PubMed: 25957691]

86. Xie BY, Wu AW. Organoid culture of isolated cells from patient-derived tissues with colorectal cancer. Chin. Med. J. (Engl). 2016; 129:2469-75. [PubMed: 27748340]

87. Drost J, van Jaarsveld RH, Ponsioen B, Zimberlin C, van Boxtel R, Buijs A, et al. Sequential cancer mutations in cultured human intestinal stem cells. Nature. 2015; 521:43-7. [PubMed: 25924068] 
88. Du Q, Geller Da. Cross-Regulation Between Wnt and NF-kB Signaling Pathways. Immunopathol Dis Ther. 2011; 1:1-18.

89. Ibrahem S, Al-Ghamdi S, Baloch K, Muhammad B, Fadhil W, Jackson D, et al. STAT3 paradoxically stimulates beta-catenin expression but inhibits beta-catenin function. Int J Exp Pathol. 2014; 95:392-400. [PubMed: 25348333]

90. Phesse TJ, Buchert M, Stuart E, Flanagan DJ, Faux M, Afshar-Sterle S, et al. Partial inhibition of gp130-Jak-Stat3 signaling prevents Wnt- $\beta$-catenin-mediated intestinal tumor growth and regeneration. Sci. Signal. 2014; 7:ra92. [PubMed: 25270258]

91. Barrett CW, Reddy VK, Short SP, Motley AK, Lintel MK, Bradley AM, et al. Selenoprotein P influences colitis-induced tumorigenesis by mediating stemness and oxidative damage. J. Clin. Invest. 2015; 125:2646-60. [PubMed: 26053663]

92. Kiraly O, Gong G, Olipitz W, Muthupalani S, Engelward BP. Inflammation-induced cell proliferation potentiates DNA damage-induced mutations in vivo. PLoS Genet. 2015; 11:e1004901. [PubMed: 25647331]

93• Nozaki K, Mochizuki W, Matsumoto Y, Matsumoto T, Fukuda M, Mizutani T, et al. Co-culture with intestinal epithelial organoids allows efficient expansion and motility analysis of intraepithelial lymphocytes. J. Gastroenterol. 2016; 51:206-13. Describes co-culture of intestinal epithelial organoids with intraepithelial lymphocytes (IELs). [PubMed: 26800996]

94. Pastuła A, Middelhoff M, Brandtner A, Tobiasch M, Höhl B, Nuber AH, et al. Three-Dimensional Gastrointestinal Organoid Culture in Combination with Nerves or Fibroblasts: A Method to Characterize the Gastrointestinal Stem Cell Niche. Stem Cells Int. 2016; 2016

95. Rogoz A, Reis BS, Karssemeijer RA, Mucida D. A 3-D enteroid-based model to study T-cell and epithelial cell interaction. J. Immunol. Methods. 2015; 421:89-95. [PubMed: 25841547]

96. Shaffiey SA, Jia H, Keane T, Costello C, Wasserman D, Quidgley M, et al. Intestinal stem cell growth and differentiation on a tubular scaffold with evaluation in small and large animals. Regen. Med. 2015; 11 rme.15.70.

97. Maloy KJ, Salaun L, Cahill R, Dougan G, Saunders NJ, Powrie F. CD4 + CD25 + T R Cells Suppress Innate Immune Pathology Through Cytokine-dependent Mechanisms. J. Exp. Med. 2003; 197:111-9. [PubMed: 12515818]

98. Gounari F, Chang R, Cowan J, Guo Z, Dose M, Gounaris E, et al. Loss of adenomatous polyposis coli gene function disrupts thymic development. Nat. Immunol. 2005; 6:800-9. [PubMed: 16025118]

99. Cheung, aF, Carter, aM, Kostova, KK., Woodruff, JF., Crowley, D., Bronson, RT., et al. Complete deletion of Apc results in severe polyposis in mice. Oncogene. 2010; 29:1857-64. [PubMed: 20010873]

100. Smits R, Van Oordt WVH, Luz A, Zurcher C, Jagmohan-Changur S, Breukel C, et al. Apc1638N: A mouse model for familial adenomatous polyposis-associated desmoid tumors and cutaneous cysts. Gastroenterology. 1998; 114:275-83. [PubMed: 9453487]

101. Dennis KL, Wang Y, Blatner NR, Wang S, Saadalla A, Trudeau E, et al. Adenomatous polyps are drivenbymicrobe-instigated focal inflammation and are controlled by IL-10-producing T cells. Cancer Res. 2013; 73:5905-13. [PubMed: 23955389]

102. Wang L, Wang Y, Song Z, Chu J, Qu X. Deficiency of interferon-gamma or its receptor promotes colorectal cancer development. J. Interferon Cytokine Res. 2015; 35:273-80. [PubMed: 25383957]

103. Tjandra SS, Hsu C, Goh I, Gurung A, Poon R, Nadesan P, et al. IFN-Beta signaling positively regulates tumorigenesis in aggressive fibromatosis, potentially by modulating mesenchymal progenitors. Cancer Res. 2007; 67:7124-31. [PubMed: 17671179]

104. Popivanova BK, Kitamura K, Wu Y, Kondo T, Kagaya T, Kaneko S, et al. Blocking TNF- a in mice reduces colorectal carcinogenesis associated with chronic colitis. J Clin Invest. 2008; 118

105. Hale LP, Greer PK. A Novel Murine Model of Inflammatory Bowel Disease and InflammationAssociated Colon Cancer with Ulcerative Colitis-Like Features. PLoS One. 2012; 7

106. Blatner NR, Mulcahy MF, Dennis KL, Scholtens D, Bentrem DJ, Phillips JD, et al. Expression of ROR $\gamma$ t Marks a Pathogenic Regulatory T Cell Subset in Human Colon Cancer. Sci Trans Med. 2012; 4 
107. Baltgalvis KA, Berger FG, Pena MMO, Davis JM, Muga SJ, Carson JA, et al. Interleukin-6 and cachexia in Apc Min /+ mice. Am J Physiol Regul Integr Comp Physiol. 2008; 294:393-401.

108. Musteanu M, Blaas L, Mair M, Schlederer M, Bilban M, Tauber S, et al. Stat3 Is a Negative Regulator of Intestinal Tumor Progression in ApcMin Mice. Gastroenterology. 2010; 138:10031011.e5. [PubMed: 19962983]

109. Pathria P, Gotthardt D, Prchal-Murphy M, Putz E-M, Holcmann M, Schlederer M, et al. Myeloid STAT3 promotes formation of colitis-associated colorectal cancer in mice. Oncoimmunology. 2015; 4:e998529. [PubMed: 26137415] 
A Source material: epithelium

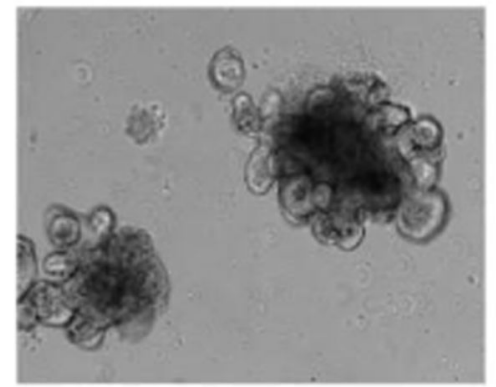

B Co-culturing material: immune/stromal cells

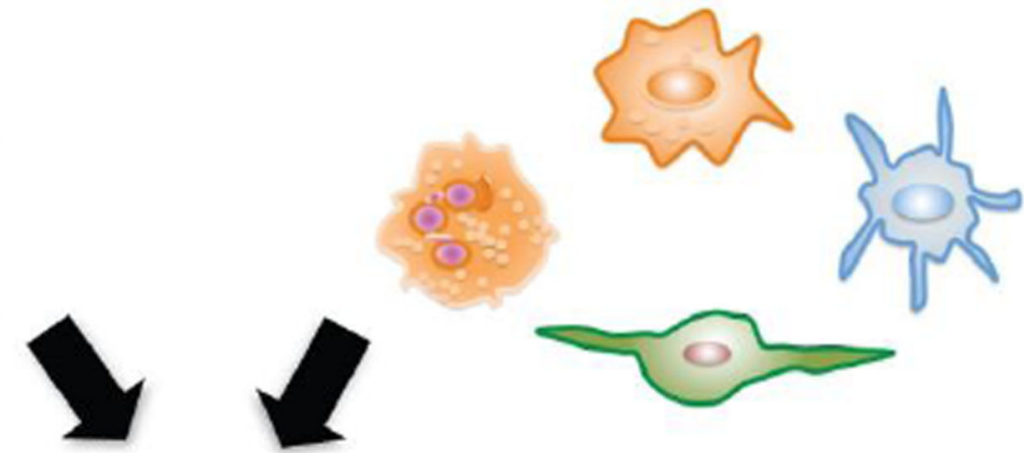

\section{Experimental platform: 3D co-mingled, 3D layered, monolayer}

D

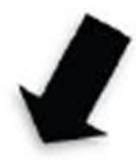

morphology, proliferation/cell death

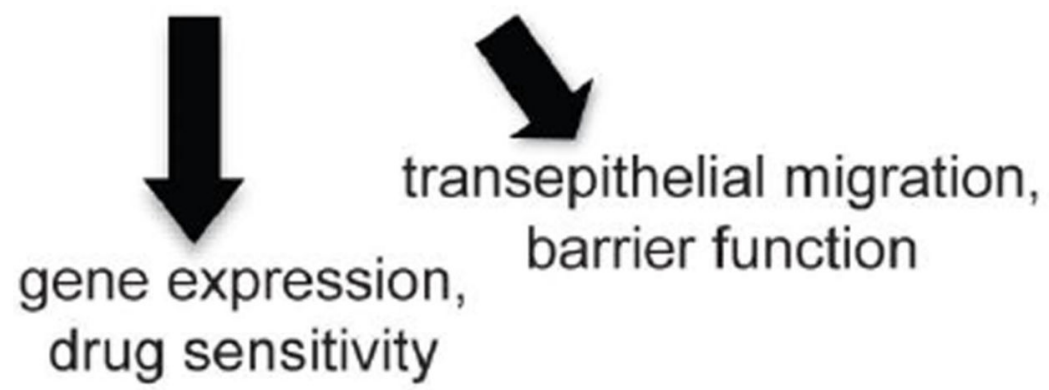

Figure 1.

Steps to utilize 3D enteroids/colonoids/tumoroids for co-culture experiments. A. Enteroid/ colonoid/tumoroid cultures can be grown readily from normal crypt (stem-cell containing) epithelium or tumors from mouse models or patient tissue. B. Studies demonstrating cocultures of enteroid/colonoid/tumoroid with various inflammatory components are rapidly emerging. Considerations for co-culturing include: which immune/stromal cell co-culture experiment will answer my experimental question? Can this immune/stromal cell type be readily purified from mice/humans for use in co-culture experiments? Will the co-cultured cells survive in $3 \mathrm{D}$ enteroid growth conditions? If possible, will the co-culture cells express a fluorescent reporter? C. Co-culture platform must be considered and can include comingling of enteroid cells with immune/stromal cells (permitting direct interaction), growing adherent cells (such as fibroblasts) and then layering enteroids in 3D matrix on top of the layer of adherent cells, or evaluating dissociated enteroids grown as monolayers on semipermeable supports with co-culture cells added to the upper (apical) or lower (basolateral) chamber. D. Analyses of co-cultures can include using biochemical or immunohistochemical analyses of morphology, proliferation, and cell death, gene expression studies, drug sensitivity, and functional tests including transepithelial migration and barrier function.

Curr Colorectal Cancer Rep. Author manuscript; available in PMC 2018 August 01. 
Table 1

Overview of historical and recent mouse models for inflammation and CRC

\begin{tabular}{|c|c|c|}
\hline Mouse Model & Phenotype & Reference \\
\hline \multicolumn{3}{|l|}{ Colitis-associated cancer (CAC) models } \\
\hline DSS 3-5 cycles & $\begin{array}{l}\text { Acute colitis with signs of diarrhea, gross rectal bleeding, and } \\
\text { weight loss. After } 5 \text { cycles, mice develop chronic colitis with } \\
\text { erosions, regenerative mucosa and dysplasia. }\end{array}$ & $\begin{array}{l}\text { Okayasu et al. [15] Cooper et } \\
\text { al. [16] }\end{array}$ \\
\hline AOM; DSS ( 1 cycle $)$ & $\begin{array}{l}\text { Colonic neoplasms by } 20 \text { weeks. Presence of tubular adenomas, } \\
\text { dysplasia and colitis with mucosal ulcerations. } \\
\text { Adenocarcinomas are positive for } \beta \text {-catenin, CO2, and iNOS } \\
\text { staining; negative for p53. }\end{array}$ & Tanaka et al. [17] \\
\hline $\begin{array}{l}\mathrm{Rag}^{-1-} ; \text { Heliobacter hepaticus infection; } \\
\text { AOM }\end{array}$ & $\begin{array}{l}\text { Chronic inflammation of the cecum and colon that progresses to } \\
\text { invasive CRC by } 3-5 \text { months. Histologically contains atypical } \\
\text { glands and desmoplastic stromal reaction. }\end{array}$ & $\begin{array}{l}\text { Maloy et al. [97] Kirchberger et } \\
\text { al. [41] }\end{array}$ \\
\hline$I I-10^{-1-}$ & $\begin{array}{l}\text { Inflammation at } 3 \text { weeks with colorectal adenocarcinoma by } 6 \\
\text { months. Inflammation is attenuated by anti-INF- } \gamma \text {. }\end{array}$ & $\begin{array}{l}\text { Berg et al. [26] Davidson et al. } \\
\text { [27] }\end{array}$ \\
\hline
\end{tabular}

Sporadic (Apc) CRC models

\begin{tabular}{|c|c|c|}
\hline$A p c^{\min /+}$ & $\begin{array}{l}\text { Derived from ENU mutagenesis screen. Autosomal dominant } \\
\text { phenotype with multiple (100s) intestinal neoplasias. Mapped to } \\
\text { truncation at amino acid } 850 \text { of } A p c \text { gene. }\end{array}$ & Su et al. [23] \\
\hline$A p c^{\Delta 468 /+}$ & $\begin{array}{l}\text { Intestinal polyps develop at } 2 \text { months of age. Can be conditional } \\
\text { as } L o x P \text { sites flank exon } 11 \text { and } 12 .\end{array}$ & Gounari et al. [98] \\
\hline Villin-Cre; Apc flex1-15/+ & $\begin{array}{l}\text { Complete deletion of } A p c \text { in intestinal epithelium. Mice } \\
\text { develop adenomas in small intestines and colon by } 4-5 \text { months } \\
\text { of age. When } A p c \text { is globally deleted, mortality decreases by } \\
30 \% \text { and there is faster progression of adenomas as compared to } \\
A p c^{\text {min/t }} \text { mice. }\end{array}$ & Cheung, et al. [99] \\
\hline$A p c^{1638 N /+}$ & $\begin{array}{l}\text { Targeted mutation at exon } 15 \text {. Multifocal cutaneous follicular } \\
\text { cysts and desmoid tumors form with an average of } 45 \text { tumors at } \\
6 \text { months of age. }\end{array}$ & Smits, et al. [100] \\
\hline$C d x 2-C r e ; A p c^{f l o x / t}(C P C-A P C)$ & $\begin{array}{l}\text { Conditional deletion of one allele of } A p c \text { under the } C d \times 2 \\
\text { promoter. Adenoma distribution in colon. }\end{array}$ & Hinoi, et al. [24] \\
\hline
\end{tabular}

IL-10 models

Foxp3-Cre-I110ra ${ }^{\text {flox/flox }}$

Cd4-Cre-II1O flox/flox $; A p c^{4468 /+}$

II2pIL10; $A p c^{4468 /+}$

$A p c^{\min /+} ;$ oral IL-10
Deletion of the IL-10 Receptor in T-helper cell lineage. Increased colitis and STAT3 signaling with elicited Th17 response as compared to wildtype.

Deletion of IL-10 in T and T-helper lineages in the background of sporadic CRC. Increased colonic polyps with enriched CRCassociated microbiota as compared to $A p c^{4468 /+}$ mice. Treatment with broad-spectrum antibiotics reduced inflammation and polyposis in colon.

Overexpression of IL-10 in CD4 ${ }^{+}$T-cells. Decreased polyposis in intestines and increased intra-polyp cytotoxicity as compared to $A p c^{\Delta 468 /+}$ mice.

Oral administration of IL-10 restores suppressive function of mesenteric lymph nodes $\mathrm{CD} 4{ }^{+} \mathrm{CD} 25^{+}$cells against pathogenic T-reg cells in order to reduce dysplastic disease and enhance survival.
Chaudhry et al. [28]

Dennis et al. (2) [31] Dennis et al. [101]

Dennis et al. (2) [31]

Chung et al. [32•]
Increased number and size of adenomas with progression to adenocarcinoma as compared to $A p c^{\min / t}$ mice.
Wang et al. [102]
Interferon models

Ifn- $\gamma^{+/-} ; A p c^{\text {min/+ }}$

\author{
adenocarcinoma as
}

Curr Colorectal Cancer Rep. Author manuscript; available in PMC 2018 August 01. 


\begin{tabular}{|c|c|c|}
\hline Mouse Model & Phenotype & Reference \\
\hline Ifnar $1^{-/-} ; A p c^{1638 N /+}$ & $\begin{array}{l}\text { Deletion of type I interferon receptor. Decreased number of } \\
\text { aggressive fibromatoses in intestines as compared to } A p c^{1638 N /+} \\
\text { mice. }\end{array}$ & Tjandra et al. [103] \\
\hline Infra $^{S 5264 /+} ;$ AOM/DSS & $\begin{array}{l}\text { Stabilization of type I interferon receptor in CAC model } \\
\text { decreases tumor formation in AOM/DSS mice. }\end{array}$ & Katlinski, 2017 [36••] \\
\hline \multicolumn{3}{|l|}{ IL-23/IL-17 models } \\
\hline $1123 r^{-1-} ; \mathrm{CPC}-\mathrm{APC}$ & $\begin{array}{l}\text { Decreased tumor load with reduced expression of IL- } 23 \text { related } \\
\text { cytokines as compared to CPC-APC mice. }\end{array}$ & Grivennikov et al. [14••] \\
\hline $1117 \mathrm{ra}^{-/-}$; CPC-APC & $\begin{array}{l}\text { Deletion of receptor for IL-17A and IL-17F. Tumor growth and } \\
\text { number were decreased as compared to CPC-APC mice. }\end{array}$ & Grivennikov et al. [14••] \\
\hline $11-17 \mathrm{re}^{-/-} ; \mathrm{AOM} / \mathrm{DSS}$ & $\begin{array}{l}\text { Deletion of a specific receptor for IL-17C. Decreased tumor } \\
\text { size and tumor load due to increased apoptosis as compared to } \\
\text { AOM/DSS mice. }\end{array}$ & Song et al. [40] \\
\hline Il-12p35-/-; AOM/DSS & $\begin{array}{l}\text { Deletion of a regulator of Th1 response. Increased tumor score } \\
\text { but milder DSS colitis as compared to AOM/DSS mice. }\end{array}$ & Richter et al. [39] \\
\hline p47phox ${ }^{-/-} ;$AOM/DSS & $\begin{array}{l}\text { Deletion of a negative regulator of IL- } 12 \text { and positive regulator } \\
\text { of IL-23. Decreased tumor score but increased DSS-induced } \\
\text { colitis, associated with less IL-23 production as compared to } \\
\text { AOM/DSS mice }\end{array}$ & Richter et al. [39] \\
\hline II-23p19--; AOM/DSS & Decreased tumor growth as compared to AOM/DSS mice. & Richter et al. [39] \\
\hline
\end{tabular}

TNFa/NF-kB pathway models

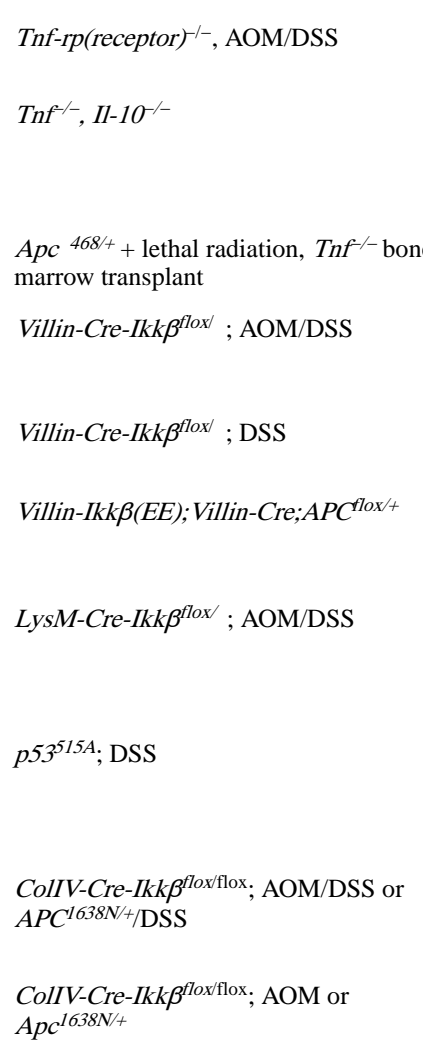

Increased tumor formation and decreased neutrophil and macrophage infiltration as compared to AOM/DSS mice.

Increased inflammatory score in mid- and distal colon and rectum compared to $I I-10^{-1-}$. $55 \%$ of cohort developed neoplastic lesions at $>15$ weeks. Colitis is decreased with antibiotics.

Decreased number of polyps.as compared to wildtype bone marrow transplant.

Deletion of $N F-k B$ signaling pathway in epithelial cells. Decreased tumor incidence secondary to increase apoptosis as compared to AOM/DSS mice.

Severe acute inflammation with increased weight loss as compared to $I k k \beta^{f l o x / \Delta} / \mathrm{DSS}$ mice.

Overexpression of $I k k \beta$ in the intestinal compartment. Increased macroscopic small intestine and colonic tumors with high levels of iNOS as compared to Villin-Cre;APC $C^{\text {llox/+ }}$ mice.

Deletion of NF-kB signaling pathway in myeloid lineage. Decreased tumor size due to downregulation of proinflammatory factors as compared to $I k k \beta^{f l o x / \Delta} ;$ AOM/DSS mice.

Hotspot mutation at R172H of p53 exerts neomorphic functions of mutant $\mathrm{p} 53$ to prolong NF-kB signaling. Increased adenomas and invasive carcinomas as compared to $\mathrm{p} 53^{+/-}$mice treated with chronic DSS.

Deletion of NF-kB signaling pathway in mesenchymal population. Decreased tumor load and immune infiltrates as compared to $I k k \beta^{\text {floxflox }}$ mice

No difference in tumor load as compared to $I k k \beta^{\text {floxflox }}$ mice
Popivanova et al. [104]

Hale et al. [105]

Blatner et al. [106]

Greten et al. [18]

Greten et al. [18]

Shaked et al. [55]

Greten et al. [18]

Cooks et al. [57•]

Koliaraki et al. [56]

Koliaraki et al. [56]

\section{IL-6/STAT3 Pathway}

Curr Colorectal Cancer Rep. Author manuscript; available in PMC 2018 August 01. 


\begin{tabular}{|c|c|c|}
\hline Mouse Model & Phenotype & Reference \\
\hline II- $\sigma^{-1-}$, AOM/DSS* & $\begin{array}{l}\text { Decreased tumor load (via decreased proliferation, STAT3 } \\
\text { signaling, CYCLIND1, COX-2, MMP9, HSP70, Bcl- } \mathrm{X}_{\mathrm{L}} \text { ) as } \\
\text { compared to AOM/DSS mice. }\end{array}$ & Grivennikov et al. [46] \\
\hline$I I-\sigma^{-/-}, A p c^{M i n /+}$ & $\begin{array}{l}\text { Decreased tumor load (via decreased STAT3 signaling) as } \\
\text { compared to } \mathrm{Apc}^{\mathrm{MinN}+} \text { mice. }\end{array}$ & Baltgalvis et al. [107] \\
\hline Villin-Cre-Stat3flox/flox; AOM/DSS & $\begin{array}{l}\text { Increased inflammatory response after DSS. Decreased tumor } \\
\text { load, multiplicity, size, and proliferation as compared to } \\
\text { Stat } 3^{\text {floxfflox}} \text {; AOM/DSS mice. }\end{array}$ & $\begin{array}{l}\text { Grivennikov et al. [46] Bollrath } \\
\text { et al. [47] }\end{array}$ \\
\hline$g p 130^{Y 757 F} ; \mathrm{AOM} / \mathrm{DSS}$ & $\begin{array}{l}\text { Global hyperactivation of STAT3 signaling. Decreased } \\
\text { inflammatory response after DSS and increased tumor load and } \\
\text { proliferation as compared to AOM/DSS mice }\end{array}$ & Bollrath et al. [47] \\
\hline Villin-Cre;Stat $3^{\text {flox/flox }} ; A c^{\text {Minl } /+}$ & $\begin{array}{l}\text { Deletion of STAT3 in epithelial lineage. Decreased tumor } \\
\text { number, but increased tumor size in aged mice; increased } \\
\text { intestinal epithelial cell proliferation, nuclear } \beta \text {-catenin, cyclin- } \\
\text { D1 as compared to Stat } 3^{\text {floxfllox; }} \text { Apc }{ }^{\text {Minl+ }} \text { mice. }\end{array}$ & Musteanu et al. [108] \\
\hline LysM-Cre;Stat ${ }^{\text {flox/flox }} ;$ AOM/DSS & $\begin{array}{l}\text { Deletion of STAT3 in myeloid population. Decreased tumor } \\
\text { growth and increased T-cell activation as compared to } \\
\text { AOM/DSS mice. }\end{array}$ & Pathria et al. [109] \\
\hline II11 ra1 ${ }^{-1-} ; \mathrm{AOM} / \mathrm{DSS}$ & $\begin{array}{l}\text { Decrease in tumor number and size with decreased STAT3 } \\
\text { signaling as compared to AOM/DSS mice. }\end{array}$ & Putoczki et al. [49] \\
\hline \multicolumn{3}{|l|}{ COX/PGE signaling Pathway } \\
\hline $\operatorname{Ptgs}^{2-\alpha} ; A p c^{\Delta 716 /+}$ & $\begin{array}{l}\text { Decreased tumor number and size as compared to } \\
\mathrm{Apc}^{\mathrm{Minl} /} \text { mice. }\end{array}$ & Oshima et al. [58] \\
\hline $\operatorname{Ptgs}^{-1-} ; \mathrm{Apc}^{\mathrm{Min} /+}$ & Decreased in tumor number as compared to $A p c^{M i n /+}$ mice. & Chulada et al. [59] \\
\hline Ptgs $2^{--} ; A p c^{M i n /+}$ & Decreased tumor number as compared to $A p c^{M i n l+}$ mice. & Chulada et al. [59] \\
\hline
\end{tabular}

Table abbreviations: DSS: dextran sodium sulfate; AOM: azoxymethane; Apc Adenomatous polyposis coli; Min multiple intestinal neoplasia. Villin: Intestinal epithelial lineage. $C d \times 2$ : Intestinal epithelial lineage. Foxp3: T-regulatory cell lineage. CD4: T and T-helper cell lineage. LysM: Myeloid lineage. ColIV Fibroblast-like lineage. 